\title{
TRANSFORMASI MINERAL PIROLUSIT PADA TEMPERATUR TINGGI
}

\author{
Transformation of Pirolusite Mineral at High Temperature
}

\author{
SOLIHIN dan ADITYA WIBAWA \\ Pusat Penelitian Geoteknologi Lembaga Ilmu Pengetahuan Indonesia \\ Jalan Sangkuriang, Kompleks LIPI, 40135, Dago, Coblong, \\ Kota Bandung, Jawa Barat 40135 \\ e-mail: zolihin@gmail.com
}

\begin{abstract}
ABSTRAK
Mangan adalah unsur penting yang digunakan oleh beberapa industri a.l. sebagai unsur pemadu dalam industri baterai dan baja khusus. Reduksi merupakan tahap yang sangat penting dalam proses pengolahan mangan. Tujuan dari penelitian ini untuk menyelidiki perilaku reduksi konsentrat mangan yang berasal dari Sumbawa. Konsentrat mangan ini mengandung pirolusit dan kuarsa. Pemanasan campuran konsentrat mangan dan batubara menghasilkan senyawa $\mathrm{Mn}_{3} \mathrm{O}_{4}$ yang stabil sampai temperatur $700^{\circ} \mathrm{C}$. Menurunnya tekanan parsial reduktor pada temperatur $800^{\circ} \mathrm{C}$ menyebabkan $\mathrm{Mn}_{3} \mathrm{O}_{4}$ teroksidasi kembali menjadi $\mathrm{Mn}_{2} \mathrm{O}_{3}$ yang stabil sampai temperatur $1100^{\circ} \mathrm{C}$. Selama pemanasan, kuarsa diperkirakan mengalami perubahan struktur kristal menjadi silika nonkristalin. Akhirnya, silika nonkristalin tersebut bereaksi dengan mangan oksida pada temperatur $1200^{\circ} \mathrm{C}$ membentuk mangan silikat.
\end{abstract}

Kata kunci: Mangan, reduksi, reaksi antar padatan, pirometalurgi.

\begin{abstract}
Manganese is an important element that is used in some industries which is commonly used as alloying element in battery and special steel industries. Reduction of manganese concentrate is very important step in manganese processing. The aim of this research is to investigate reduction behaviour of manganese concentrate obtained from Sumbawa. The concentrate consisted of pyrolusite and quartz. The heating of the mixed manganese concentrate and coal resulted in the formation of $\mathrm{Mn}_{3} \mathrm{O}_{4}$, which was stable until $700^{\circ} \mathrm{C}$. The decreasing of partial pressure of reductor during heating at $800^{\circ} \mathrm{C}$ lead to the oxidation of $\mathrm{Mn}_{3} \mathrm{O}_{4}$ to become $\mathrm{Mn}_{2} \mathrm{O}_{3}$, which was stable until $1100^{\circ} \mathrm{C}$. Meanwhile during heating, the crystal structure of quartz seems to change from crystalline to amorphous structure of silica. Finally, this amorphous structure of silica reacted with manganese oxide at $1200^{\circ} \mathrm{C}$ to form manganese silicate.
\end{abstract}

Keywords: Manganese, reduction, solid state reaction, pyrometallurgy.

\section{PENDAHULUAN}

Mangan merupakan material penting yang digunakan dalam berbagai industri seperti baja tahan aus dan baterai (Bélanger, Brousse dan Long, 2008; Pribulova, Babic dan Baricova, 2011; Qian, Feng dan Zhang, 2011; Agunsoye, Talabi dan Bello, 2015; Borek dkk., 2015). Indonesia memiliki deposit bijih mangan yang cukup signifikan. Salah satu deposit mangan terdapat di beberapa daerah tertentu di provinsi Nusa Tenggara Barat (SRK Consulting, 2015). Sampai saat ini di Indonesia kadar mangan telah dapat ditingkatkan melalui proses mineral dressing yang menghasilkan konsentrat mangan. Konsentrat mangan tersebut dapat diproses menjadi bahan baku untuk industri ferromangan, baterai, katalis dan lain-lain. 
Mangan memiliki valensi yang bervariasi dari +4, +3, dan + 2 (Tang $d k k_{\text {., 2014). Terdapat }}$ berbagai senyawa mangan oksida dengan berbagai nilai valensi, yakni $\mathrm{MnO}_{2}, \mathrm{Mn}_{2} \mathrm{O}_{3}$, $\mathrm{Mn}_{3} \mathrm{O}_{4}$ dan $\mathrm{MnO}$ (Krivenko dkk., 2010). Mangan oksida biasanya diolah melalui proses reduksi pada temperatur tinggi, kemudian diikuti oleh proses pelarutan dan pengendapan pada temperatur rendah (Artamonova, Gorichev dan Godunov, 2013). Proses reduksi pada temperatur tinggi dimaksudkan untuk mempersiapkan mangan oksida agar mudah dilarutkan pada temperatur rendah (Wang $d k k$., 2017). Penelitian proses reduksi mangan pada temperatur tinggi sangat diperlukan untuk mengetahui mekanisme reaksi reduksi mangan oksida dan menentukan rentang temperatur reduksi yang optimal. Oleh karena itu, penelitian ini bertujuan untuk mengamati mekanisme reaksi reduksi mangan oksida.

\section{METODE}

Konsentrat bijih mangan diperoleh dari daerah Sumbawa. Metode yang dipilih dalam penelitian ini adalah proses reduksi pada temperatur tinggi menggunakan batubara. Sebelum diproses, terhadap konsentrat dilakukan analisa X-Ray Flouresence (XRF) dan X-Ray Diffraction (XRD) untuk mengetahui kadar dan komposisi mineral yang terkandung dalam konsentrat tersebut. Konsentrat mangan oksida dicampur batubara (Fixed Carbon 28\%). Persen berat batubara pada setiap percontoh adalah $20 \%$. Campuran tersebut kemudian dijadikan pelet dengan diameter sekitar $1 \mathrm{~cm}$. Pelet ditempatkan dalam tungku muffle sebagai reaktor untuk proses reduksi. Proses reduksi dilakukan selama 4 jam pada temperatur yang bervariasi (700 $1200^{\circ} \mathrm{C}$ ). Percontoh hasil proses reduksi kemudian dianalisis menggunakan XRD untuk mengetahui senyawa/fasa yang ada dalam percontoh. Analisis morfologi permukaan percontoh dan distribusi unsur (mapping) dalam percontoh dilakukan melalui peralatan Scanning Electron Microscope (SEM) yang dilengkapi Energy Dispersive X-ray Spectroscopy (EDS). Perilaku panas percontoh diketahui melalui uji Differential Thermal Analysis (DTA) yang dikombinasikan dengan Thermo Gravimetry (TG).

\section{HASIL DAN PEMBAHASAN}

Pola XRD dari konsentrat mangan diperlihatkan pada Gambar 1. Mineral yang terdapat dalam konsentrat adalah mangan dioksida $\left(\mathrm{MnO}_{2}\right.$, pirolusit) dan kuarsa $\left(\mathrm{SiO}_{2}\right)$. Hasil analisis XRF terhadap konsentrat mangan oksida ditunjukkan pada Tabel 1. Unsur utama adalah $\mathrm{Mn}, \mathrm{Si}$ dan O. Selain itu terdapat unsur minor Fe dengan kadar $4,2 \%$, serta unsur lainnya dengan total kadar sekitar 0,50\%. Keberadaan $\mathrm{MnO}_{2}$ merupakan hal yang sangat lazim pada bijih atau konsentrat mangan (Fahim dkk., 2013; SRK Consulting, 2015). Pemisahan fisik pada proses konsentrasi (benefisiasi) tidak akan mengubah senyawa mangan oksida tersebut.

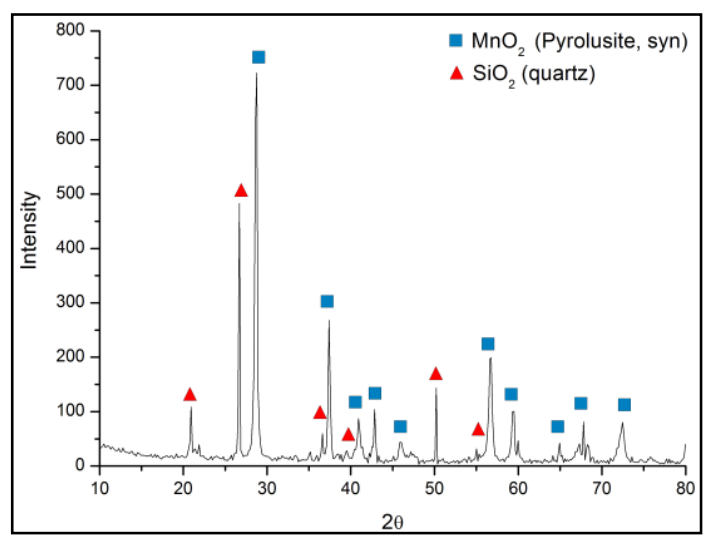

Gambar 1. Pola XRD percontoh konsentrat mangan

Tabel 1. Komposisi unsur konsentrat mangan oksida Sumbawa

\begin{tabular}{lc}
\hline \multicolumn{1}{c}{ Unsur } & \% Berat \\
\hline $\mathrm{Mn}$ & 51.2 \\
$\mathrm{Fe}$ & 4.2 \\
$\mathrm{Si}, \mathrm{O}$ & 44.1 \\
$\mathrm{Ni}, \mathrm{Ag}, \mathrm{Zn}, \mathrm{Sr}, \mathrm{Mo}, \mathrm{As}, \mathrm{V}, \mathrm{Cd}, \mathrm{Pd}$ & 0.50 \\
\hline
\end{tabular}

Percontoh hasil proses pemanasan pada temperatur $700-1200^{\circ} \mathrm{C}$ diperlihatkan pada Gambar 2. Pada temperatur $700^{\circ} \mathrm{C}, \mathrm{MnO}_{2}$ sudah bertransformasi menjadi $\mathrm{Mn}_{3} \mathrm{O}_{4}$ yang merupakan senyawa transisi jaringan $\mathrm{MnO}$ dan $\mathrm{MnO}_{2}$. Sementara itu pada temperatur ini, kuarsa $\left(\mathrm{SiO}_{2}\right)$ masih stabil tidak bereaksi. Reaksi transformasi $\mathrm{MnO}_{2}$ menjadi $\mathrm{Mn}_{3} \mathrm{O}_{4}$ adalah sebagai berikut:

$3 \mathrm{MnO}_{2}+2 \mathrm{CO} \rightarrow \mathrm{Mn}_{3} \mathrm{O}_{4}+2 \mathrm{CO}_{2}$ 


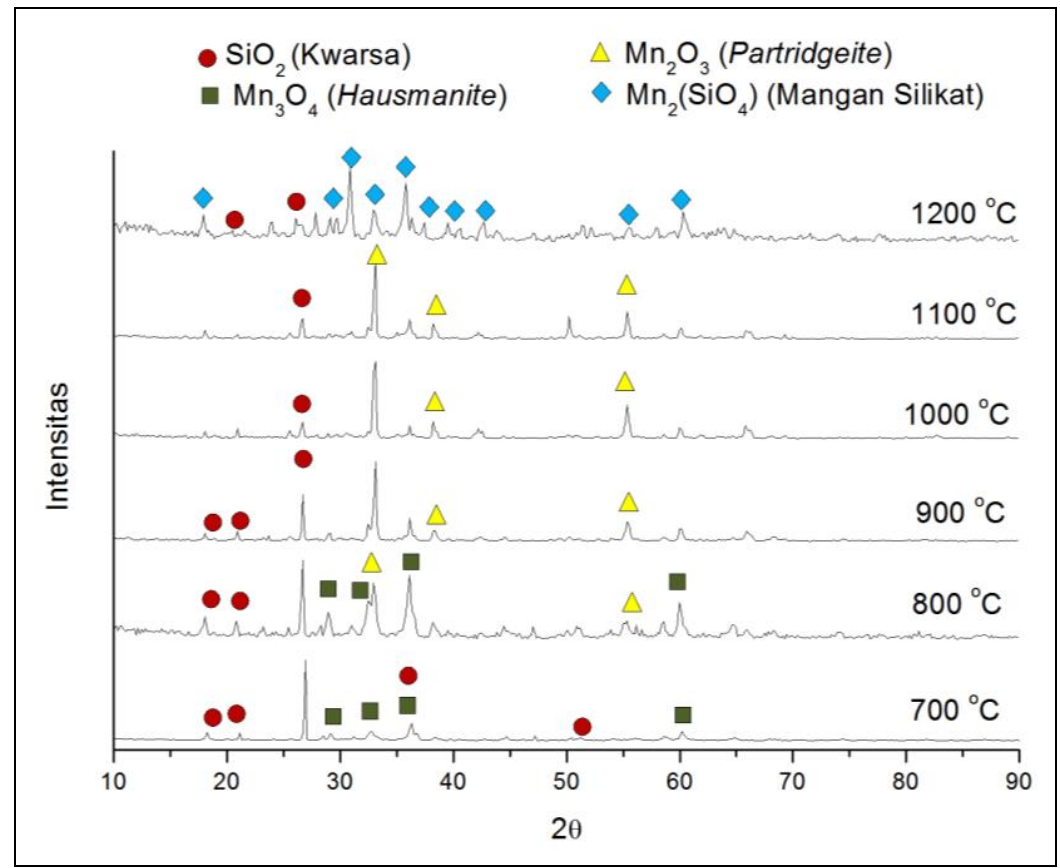

Gambar 2. Pola XRD dari percontoh setelah proses reduksi pada temperatur $700-1200{ }^{\circ} \mathrm{C}$

Pada temperatur $800^{\circ} \mathrm{C}$ sebagian $\mathrm{Mn}_{3} \mathrm{O}_{4}$ bertransformasi menjadi $\mathrm{Mn}_{2} \mathrm{O}_{3}$. Terbentuknya $\mathrm{Mn}_{2} \mathrm{O}_{3}$ dari $\mathrm{Mn}_{3} \mathrm{O}_{4}$ mengubah valensi mangan dari +4 menjadi +3 . Reaksi transformasi $\mathrm{Mn}_{3} \mathrm{O}_{4}$ menjadi $\mathrm{Mn}_{2} \mathrm{O}_{3}$ adalah sebagai berikut.

$4 \mathrm{Mn}_{3} \mathrm{O}_{4}+\mathrm{O}_{2} \rightarrow 6 \mathrm{Mn}_{2} \mathrm{O}_{3}$

Walaupun terjadi pengurangan nilai valensi, reaksi transformasi $\mathrm{Mn}_{3} \mathrm{O}_{4}$ menjadi $\mathrm{Mn}_{2} \mathrm{O}_{3}$ bukan merupakan reaksi pengurangan (reduksi) oksigen tetapi justru reaksi oksidasi (penambahan oksigen) karena reaksi ini memerlukan oksigen agar tetap berlangsung. Tetapi penelusuran literatur yang relevan dengan unit proses pengolahan mangan pada temperatur tinggi menunjukkan sebaliknya, yakni urutan proses reduksi adalah $\mathrm{MnO}_{2}$, $\mathrm{Mn}_{2} \mathrm{O}_{3}, \mathrm{Mn}_{3} \mathrm{O}_{4}$ dan $\mathrm{Mn}$ (Ramesh $d k k$., 2008; Şeşen, 2017). Perbedaan ini kemungkinan disebabkan setelah terbentuknya $\mathrm{Mn}_{3} \mathrm{O}_{4}$ tekanan parsial reduktor yang sangat jauh berkurang dibanding tekanan parsial oksigen. Konsumsi reduktor pada tahap awal reduksi pirolusit $\left(\mathrm{MnO}_{2}\right)$ sangat tinggi. Urutan konsumsi reduktor adalah $\mathrm{MnO}_{2}>\mathrm{Mn}_{2} \mathrm{O}_{3}>\mathrm{MnO}$ dengan perbandingan konsumsi reduktor untuk mereduksi $\mathrm{MnO}_{2}$ jauh lebih besar dibanding kebutuhan reduktor untuk mereduksi $\mathrm{MnO}$ (Ramesh, Chen, Chen, \& Han, 2008). Oleh karena itu, berkaitan dengan fakta teroksidasinya kembali $\mathrm{Mn}_{3} \mathrm{O}_{4}$ menjadi $\mathrm{Mn}_{2} \mathrm{O}_{3}$, sangat besar kemungkinan bahwa reduktor telah banyak terkonsumsi pada tahap reduksi $\mathrm{MnO}_{2}$ menjadi $\mathrm{Mn}_{2} \mathrm{O}_{3}$ dan $\mathrm{Mn}_{3} \mathrm{O}_{4}$. Hal ini menyebabkan sisa reduktor sangat kecil sehingga menurunkan tekanan parsial reduktor tersebut. Akibatnya adalah naiknya tekanan parsial oksigen sehingga mendorong terjadinya reaksi oksidasi tersebut.

Pada temperatur $900^{\circ} \mathrm{C}$, hampir seluruh $\mathrm{Mn}_{3} \mathrm{O}_{4}$ tereduksi menjadi $\mathrm{Mn}_{2} \mathrm{O}_{3}$, oleh karena itu dapat disimpulkan bahwa temperatur $900^{\circ} \mathrm{C}$ merupakan temperatur pembentukan signifikan $\mathrm{Mn}_{2} \mathrm{O}_{3}$. Kenaikan temperatur menyebabkan pembentukan $\mathrm{Mn}_{2} \mathrm{O}_{3}$ semakin progresif. Keberadaan senyawa $\mathrm{Mn}_{2} \mathrm{O}_{3}$ ini stabil dan semakin signifikan terbentuk sampai temperatur $1100^{\circ} \mathrm{C}$.

Hal yang menarik lainnya selama proses transformasi mangan oksida adalah bahwa puncak intensitas kuarsa terlihat semakin menurun dengan naiknya temperatur dari 700 sampai $1100^{\circ} \mathrm{C}$. Hal ini mengindikasikan bahwa sebagian kuarsa bertransformasi menjadi silika dengan struktur yang berbeda. Tidak terdeteksinya senyawa silika dengan struktur berbeda ini merupakan indikasi bahwa struktur dari senyawa silika tersebut 
adalah non-kristalin (amorphous). Struktur silika non-kristalin merupakan struktur yang paling reaktif dibanding jenis struktur silika lainnya. Pada temperatur $1200{ }^{\circ} \mathrm{C}$ terjadi reaksi antara silika non kristalin tersebut dengan $\mathrm{Mn}_{2} \mathrm{O}_{3}$ menghasilkan mangan silikat $\left(\mathrm{Mn}_{2}\left(\mathrm{SiO}_{4}\right)\right)$. Reaksi pembentukan mangan silikat dari $\mathrm{Mn}_{2} \mathrm{O}_{3}$ adalah sebagai berikut.

$2 \mathrm{Mn}_{2} \mathrm{O}_{3}+2 \mathrm{SiO}_{2} \rightarrow 2 \mathrm{Mn}_{2}\left(\mathrm{SiO}_{4}\right)+\mathrm{O}_{2}$

Dari persamaan ini terlihat bahwa reaksi pembentukan mangan silikat merupakan reaksi oksidasi. Penjelasan mengenai fenomena oksidasi ini akan lebih dijelaskan pada uraian selanjutnya.

Fenomena perubahan $\mathrm{MnO}_{2}$ menjadi $\mathrm{Mn}_{3} \mathrm{O}_{4}$ dan $\mathrm{Mn}_{2} \mathrm{O}_{3}$ juga terjadi pada percobaan yang dilakukan peneliti sebelumnya menggunakan bijih mangan dalam jalur $\mathrm{Na}^{-\mathrm{Ca}^{-}}$karbonat (Sorensen $d k k ., 2010$ ) dan juga dalam bijih yang masih mengandung besi (Kivinen, Krogerus dan Daavittila, 2010). Tetapi kondisi geokimia bijih yang berbeda ternyata memperlihatkan sedikit perbedaan. Untuk bijih yang berada dalam jalur $\mathrm{Na}$, Ca- karbonat terjadi juga reaksi pembentukan senyawa lain, di antaranya adalah senyawa yang mirip dengan mineral merwinite (magnesium kalsium - oksida silikat) sedangkan pada bijih yang mengandung besi atau alumunium akan terjadi pembentukan senyawa yang mirip dengan mineral garnet (mangan aluminum silikat), galaxite (mangan aluminum barium silikat) dan lain-lain (Sorensen $d k k ., 2010$ ). Berbeda dengan percontoh dari Sumbawa yang hanya mengandung oksida mangan dan silika, maka selain oksida, komponen lain yang terbentuk adalah senyawa yang mirip dengan mineral kaliophilite (mangan silikat).

Gambar 3 memperlihatkan morfologi dari percontoh hasil proses pemanasan pada temperatur $700{ }^{\circ} \mathrm{C}$. Terlihat bahwa permukaan bijih mangan masih relatif masif, dan hanya terdapat pori yang relatif kecil. Hal ini mengindikasikan bahwa reaksi reduksi kurang berjalan dengan signifikan. Tetapi bila mengacu pada Gambar 2, walaupun pengamatan visual belum mengindikasikan reaksi reduksi yang signifikan, hasil analisis menunjukkan bahwa telah terjadi transformasi $\mathrm{MnO}_{2}$ menjadi $\mathrm{Mn}_{3} \mathrm{O}_{4}$. Hal ini berarti sebagian oksigen telah direduksi oleh batubara (atau karbon dioksida) dan menghasilkan senyawa intermediate $\mathrm{Mn}_{3} \mathrm{O}_{4}$. Pengurangan oksigen tersebut jelas akan meninggalkan rongga-rongga retakan karena adanya oksigen yang berusaha keluar dari butiran. Profil mapping pada Gambar 3 juga memperlihatkan bahwa distribusi unsur dalam percontoh hasil reduksi mangan terlihat hampir sama dengan distribusi unsur oksigen. Hal ini mengindikasikan bahwa senyawa yang berkaitan dengan mangan yang ada pada percontoh adalah oksida mangan $\left(\mathrm{Mn}_{2} \mathrm{O}_{3}\right)$.
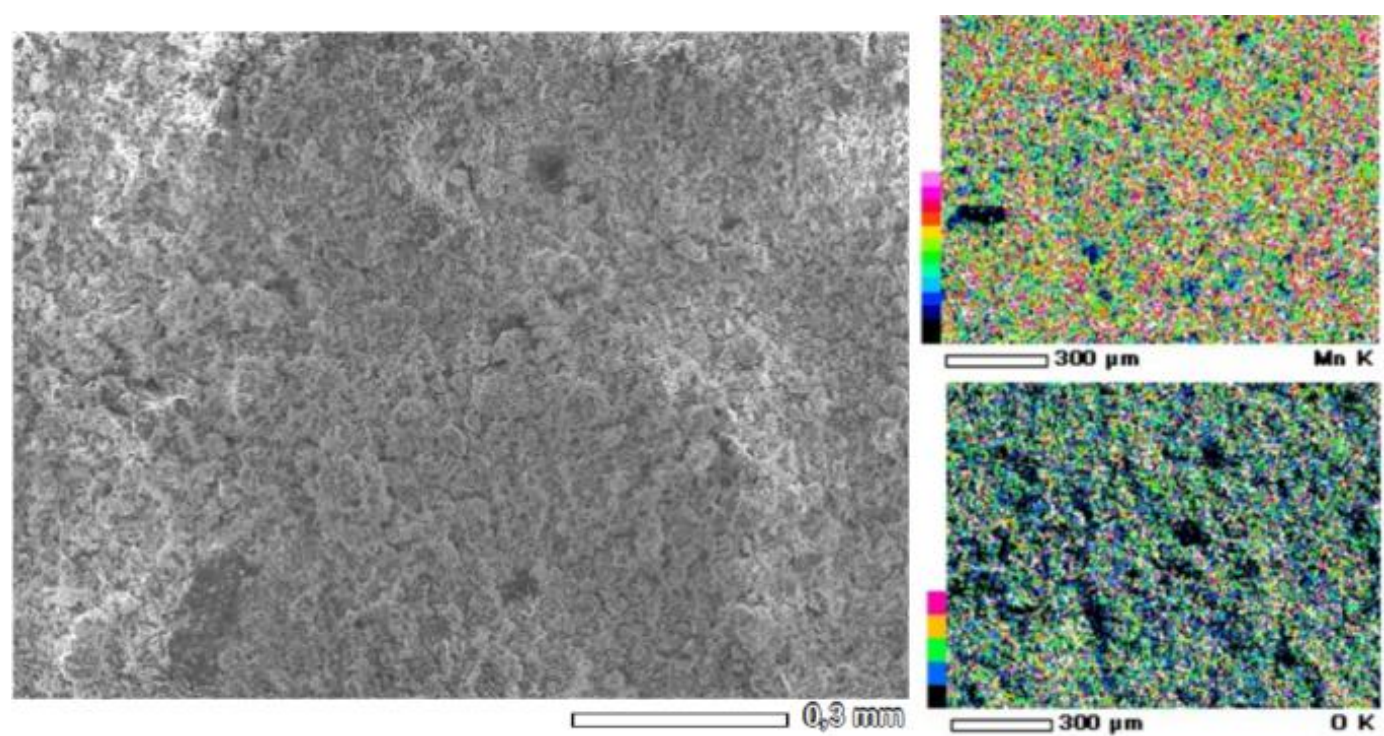

Gambar 3. Morfologi mangan hasil proses reduksi pada temperatur $700^{\circ} \mathrm{C}$ 
Gambar 4 memperlihatkan morfofologi percontoh hasil proses pemanasan pada temperatur $800{ }^{\circ} \mathrm{C}$. Morfologi pada percontoh hasil proses pemanasan pada temperatur ini agak berbeda dengan percontoh hasil proses reduksi pada temperatur $700^{\circ} \mathrm{C}$. Terlihat bahwa morfologi percontoh hasil proses pemanasan pada temperatur $800^{\circ} \mathrm{C}$ relatif kurang masif dibanding dengan morfologi percontoh hasil proses pemanasan pada temperatur $700^{\circ} \mathrm{C}$. Menurut pola XRD percontoh hasil proses pemanasan pada 800 ${ }^{\circ} \mathrm{C}$ (Gambar 2), pada temperatur ini telah terjadi reaksi oksidasi mangan oksida. Reaksi oksidasi ini akan meningkatkan volume senyawa sehingga pada gilirannya akan meningkatkan tegangan dalam percontoh. Akumulasi peningkatan tegangan dalam tersebut akan mengakibatkan munculnya retakan yang menjalar dari dalam percontoh hingga permukaan. Hasil mapping unsur mangan terhadap percontoh yang dipanaskan pada temperatur $800{ }^{\circ} \mathrm{C}$ tidak memperlihatkan perbedaan yang relatif signifikan dengan hasil mapping terhadap percontoh yang dipanaskan pada temperatur $700{ }^{\circ} \mathrm{C}$. Hasil mapping unsur oksigen terhadap percontoh yang dipanaskan pada temperatur 700 dan $800{ }^{\circ} \mathrm{C}$ memperlihatkan bahwa konsentrasi oksigen pada percontoh yang dipanaskan pada $800{ }^{\circ} \mathrm{C}$ relatif lebih banyak dibanding dari percontoh yang dipanaskan pada temperatur $700{ }^{\circ} \mathrm{C}$. Hal ini jelas mengindikasikan bahwa telah terjadi penambahan oksigen (oksidasi) yang siginifikan pada percontoh yang dipanaskan pada temperatur $800{ }^{\circ} \mathrm{C}$. Fakta ini sangat sesuai dengan hasil analisis XRD terhadap percontoh yang dipanaskan pada temperatur $800^{\circ} \mathrm{C}$ (Gambar 2), yaitu hasil XRD tersebut memperlihatkan bahwa pada temperatur 800 ${ }^{\circ} \mathrm{C}$ telah terjadi reaksi oksidasi yang menghasilkan $\mathrm{Mn}_{2} \mathrm{O}_{3}$.

Gambar 5 memperlihatkan morfologi dan mapping unsur dari percontoh hasil proses reduksi pada temperatur $1200^{\circ} \mathrm{C}$. Hasil mapping unsur mangan dan unsur oksigen memperlihatkan bahwa distribusi mangan dan oksigen sangat mirip. Hal ini jelas mengindikasikan bahwa mangan masih terikat bersama oksigen. Namun berdasarkan hasil analisis XRD (Gambar 2), pada temperatur ini mangan tidak berada dalam bentuk oksida mangan $\left(\mathrm{Mn}_{2} \mathrm{O}_{3}\right)$ tetapi dalam bentuk mangan silikat $\left(\mathrm{Mn}_{2}\left(\mathrm{SiO}_{4}\right)\right)$.
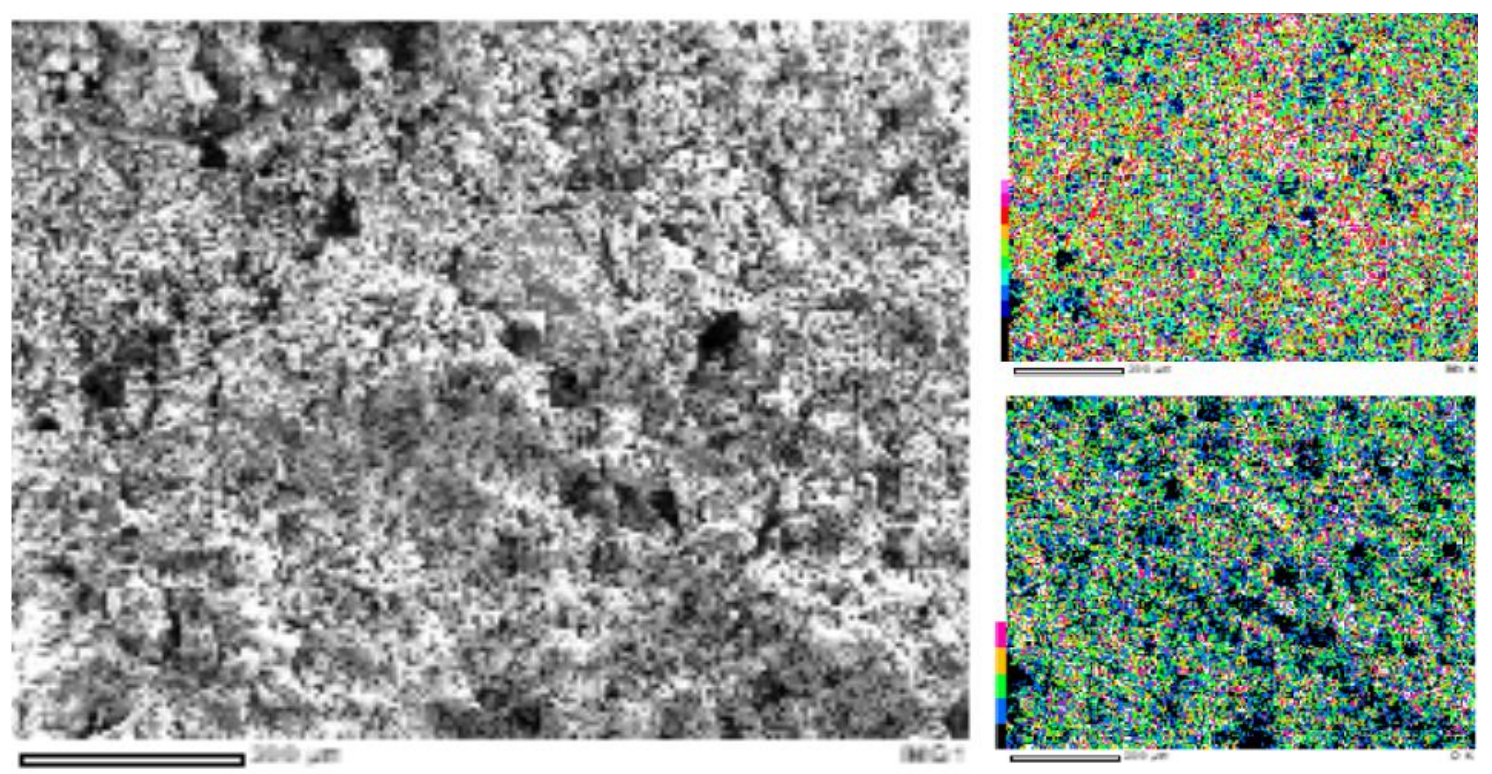

Gambar 4. Morfologi mangan hasil proses reduksi pada temperatur $1000{ }^{\circ} \mathrm{C}$ 

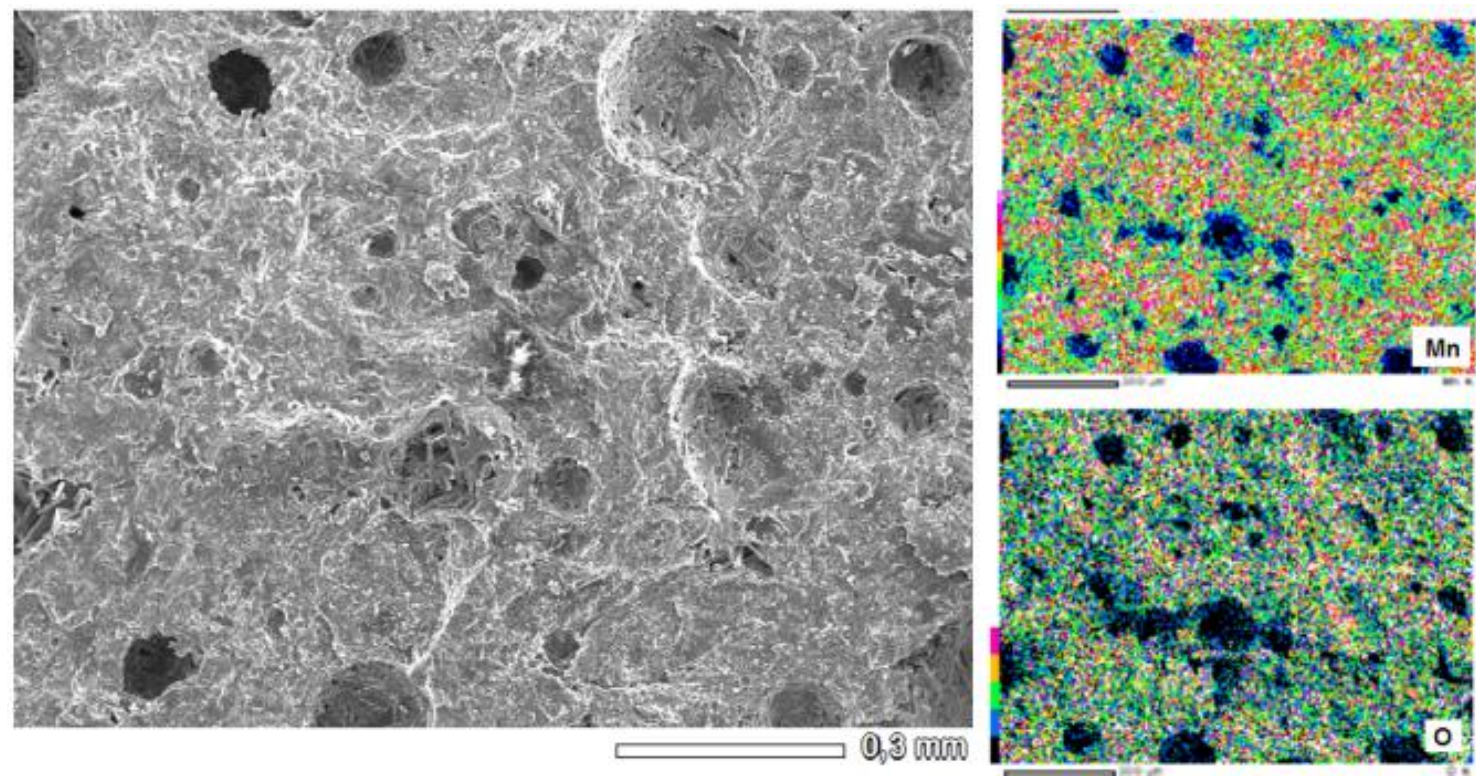

Gambar 5. Morfologi mangan hasil proses reduksi pada temperatur $1200{ }^{\circ} \mathrm{C}$

Morfologi percontoh hasil proses reduksi pada temperatur $1200{ }^{\circ} \mathrm{C}$ memperlihatkan bahwa pada permukaan percontoh terlihat banyak rongga-rongga dengan ukuran antara $0,1-0,2$ $\mathrm{mm}$. Morfologi percontoh dengan ronggarongga tersebut merupakan morfologi yang biasa terlihat pada bijih yang menghasilkan produk reaksi berupa gas, seperti pada percontoh hasil reduksi bijih besi ataupun bijih nikel. Dalam reaksi reduksi, ronggarongga tersebut merupakan ruang kosong yang dihasilkan oleh reaksi pengambilan oksigen yang terikat dalam mineral oksida mangan oleh gas $\mathrm{CO}$ ataupun karbon padatan. Produk gas yang dihasilkan dari reaksi reduksi adalah $\mathrm{CO}_{2}$. Gas $\mathrm{CO}_{2}$ ini cenderung mengalir keluar dari bijih dengan tekanan tertentu. Tekanan ini menyebabkan pecahnya bagian tertentu membentuk rongga yang cukup besar.

Berbeda dengan proses reduksi; fluida reaktan dan produk reaksi adalah masing-masing gas $\mathrm{CO}$ dan $\mathrm{CO}_{2}$, reaksi pembentukan mangan silikat pada temperatur $1200{ }^{\circ} \mathrm{C}$ tidak melibatkan reduktor. Walaupun tidak melibatkan reduktor, reaksi pembentukan silikat ini tetap menghasilkan produk reaksi berupa gas, yakni oksigen. Akumulasi gas oksigen yang dihasilkan oleh reaksi pembentukan mangan silikat ini akan menyebabkan tekanan pada percontoh yang pada gilirannya akan memunculkan ronggarongga pada percontoh tersebut.

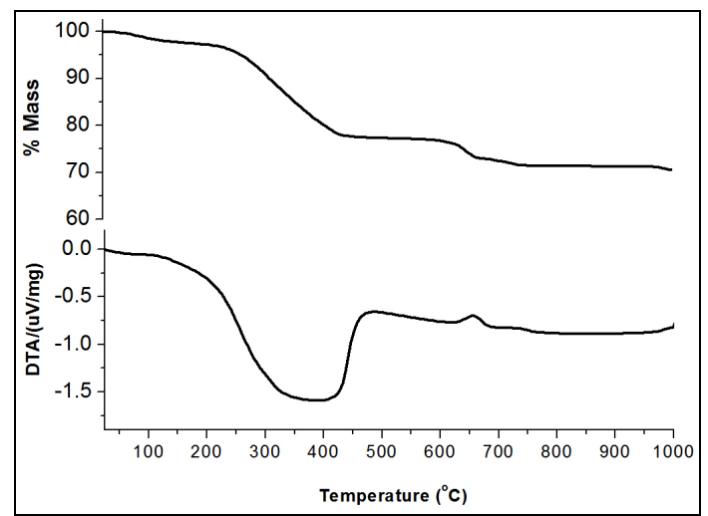

Gambar 6. Profil TG/DTA dari campuran konsentrat mangan dan batubara

Ketiadaan reduktor pada rentang temperatur percobaan pemanasan ini $\left(700-800{ }^{\circ} \mathrm{C}\right)$ dapat dikonfirmasi melalui profil TG-DTA dari campuran konsentrat mangan dan batubara yang diperlihatkan pada Gambar 6. Kurva TG dari gambar tersebut memperlihatkan terjadinya penurunan berat percontoh yang sangat signifikan pada rentang temperatur sekitar $200-400{ }^{\circ} \mathrm{C}$ dan juga sedikit penurunan berat pada rentang temperatur sekitar 650-700 ${ }^{\circ} \mathrm{C}$. Sementara itu, pada gambar yang sama, kurva DTA memperlihatkan adanya reaksi 
eksotermik yang besar pada temperatur sekitar 200-400 ${ }^{\circ} \mathrm{C}$ dan reaksi endotermik pada temperatur $650-700{ }^{\circ} \mathrm{C}$. Penurunan massa dan terjadinya reaksi eksotermik pada rentang temperatur $200-400 \quad{ }^{\circ} \mathrm{C}$ merupakan reaksi pembentukan $\mathrm{CO}$ dari batu bara sesuai persamaan reaksi sebagai berikut.

$2 \mathrm{C}+\mathrm{O}_{2} \rightarrow 2 \mathrm{CO}$

Sedangkan reaksi endothermik yang disertai sedikit penurunan berat yang terjadi pada temperatur $650-700{ }^{\circ} \mathrm{C}$ adalah reaksi reduksi pirolusit $\left(\mathrm{MnO}_{2}\right)$ menjadi $\mathrm{Mn}_{3} \mathrm{O}_{4}$ sesuai persamaan reaksi (1).

Penurunan berat percontoh sampai temperatur sekitar $400{ }^{\circ} \mathrm{C}$ adalah sekitar $20 \%$. Mengingat batubara yang ditambahkan adalah sekitar 20\%, maka persentase penurunan massa yang cukup tinggi ini mengindikasikan telah terbakarnya hampir seluruh batubara pada temperatur $400{ }^{\circ} \mathrm{C}$. Ramesh $d k k$. (2008) melaporkan hasil penelitiannya bahwa reaksi reduksi tahap pertama untuk mereduksi $\mathrm{MnO}_{2}$ memerlukan reduktor yang sangat besar. $\mathrm{Di}$ sisi lain, berdasar perhitungan stoikhiometri, gas CO yang dihasilkan sebenarnya cukup untuk mereduksi mangan tetapi mengingat sifat gas adalah mudah menyebar maka gas CO yang terbentuk akan menyebar dan keluar dari tungku muffle. Penurunan volume gas $\mathrm{CO}$ yang disebabkan oleh konsumsi reduktor yang tinggi pada reduksi tahap pertama serta reductor loss (karena gas reduktor menyebar keluar) ini mengakibatkan tekanan parsial gas CO semakin kecil sehingga kondisi atmosfir permukaan percontoh menjadi oksidatif. Atmosfir yang oksidatif ini menyebabkan terjadinya reaksi oksidasi sesuai persamaan reaksi (2).

Tabel 2 menampilkan hasil analisis EDS terhadap percontoh hasil pemanasan pada temperatur $1200{ }^{\circ} \mathrm{C}$. Pengukuran dilakukan pada dua morfologi area yang berbeda dalam percontoh (Area 1 dan Area 2). Perbandingan persen atom rata-rata dari atom $\mathrm{Si}$ dan $\mathrm{O}$ menunjukkan perbandingan relatif $\mathrm{Si}: \mathrm{O}=1: 4$. Hasil analisis EDS ini seiring dengan hasil analisis XRD yaitu senyawa bergugus Si-O yang terdapat pada percontoh yang dipanggang pada temperatur $1200{ }^{\circ} \mathrm{C}$ adalah gugus silikat $\left(-\mathrm{SiO}_{4}\right)$, yang memiliki perbandingan $\mathrm{Si}: \mathrm{O}=1: 4$.
Table 2. Hasil analisis EDS terhadap percontoh hasil pemanasan pada temperatur $1200^{\circ} \mathrm{C}$

\begin{tabular}{llll}
\hline \multirow{2}{*}{ Unsur } & \multicolumn{2}{l}{ \% Atom } & \\
\cline { 2 - 4 } & Area 1 & Area 2 & Rata-rata \\
\hline $\mathrm{Mn}$ & 38.62 & 37.19 & 37.91 \\
$\mathrm{Si}$ & 11.91 & 12.57 & 12.24 \\
$\mathrm{O}$ & 40.49 & 41.45 & 40.97 \\
$\mathrm{Ca}$ & 3.63 & 3.65 & 3.64 \\
$\mathrm{Fe}$ & 3.48 & 3.46 & 3.47 \\
$\mathrm{Al}$ & 1.74 & 1.51 & 1.62 \\
$\mathrm{~K}$ & 0.12 & 0.17 & 0.15 \\
\hline & 100.00 & 100.00 & 100.00 \\
\hline
\end{tabular}

\section{KESIMPULAN}

Pemanasan campuran konsentrat mangan dan batubara asal Sumbawa pada rentang temperatur $\quad 700-1200 \quad{ }^{\circ} \mathrm{C}$ memperlihatkan fenomena transformasi oksida-oksida melalui reaksi reduksi dan oksidasi. Senyawa yang pertama yang teramati pada temperatur $700{ }^{\circ} \mathrm{C}$ adalah Hausmanite $\left(\mathrm{Mn}_{3} \mathrm{O}_{4}\right)$ yang merupakan hasil transformasi dari pirolusit $\left(\mathrm{MnO}_{2}\right)$. Hausmanite tetap stabil sampai temperatur 700 ${ }^{\circ} \mathrm{C}$, tetapi kemudian mulai bertransformasi kembali menjadi partridgeite melalui reaksi oksidasi pada temperatur $800{ }^{\circ} \mathrm{C}$. Reaksi oksidasi ini disebabkan menurunnya tekanan parsial reduktor yang diiringi dengan naiknya tekanan parsial oksigen. Menurunnya tekakan parsial reduktor disebabkan konsumsi reduktor yang besar pada tahapan sebelumnya, yakni transformasi pirolusit menjadi hausmanite serta terjadinya reductor loss. Partridgeitte stabil sampai temperatur $1100{ }^{\circ} \mathrm{C}$. Pemanasan lebih lanjut sampai temperatur $1200 \quad{ }^{\circ} \mathrm{C}$ mentrasformasi partridgeitte dan silika menjadi mangan silikat.

\section{UCAPAN TERIMA KASIH}

Penulis mengucapkan terima kasih kepada Dr. Anggoro Tri Mursito yang telah mensuplai konsentrat bijih mangan Sumbawa. Ucapan terima kasih juga diberikan kepada para teknisi di laboratorium Kimia Mineral dan para staf di bagian umum Pusat Penelitian Geoteknologi yang telah memfasilitasi penggunaan peralatan proses dan peralatan analisis. 


\section{DAFTAR PUSTAKA}

Agunsoye, J. O., Talabi, S. I. and Bello, O. (2015) "Wear characteristics of heat-treated hadfield austenitic manganese steel for engineering application," Advances in Production Engineering \& Management, 10(2), pp. 97107. doi: 10.14743/apem2015.2.195.

Artamonova, I. V., Gorichev, I. G. and Godunov, E. B. (2013) "Kinetics of manganese oxides dissolution in sulphuric acid solutions containing oxalic acid," Engineering, 05(09), pp. 714-719. doi: 10.4236/eng.2013.59085.

Bélanger, D., Brousse, T. and Long, J. W. (2008) "Manganese oxides: Battery materials make the leap to electrochemical capacitors," in Rajeshwar, K. (ed.) The Electrochemical Society Interface. The Electrochemical Society, pp. 49-52. Available at: https://www.electrochem.org/dl/interface/spr/s pr08/spr08_p49-52.pdf.

Borek, W., Tanski, T., Jonsta, J. and L., C. (2015) "Structure and mechanical properties of highMn TWIP steel after their thermo-mechanical and heat treatments," in 24th International Conference on Metallurgy and Materials Metal 2015. Brno: METAL 2015, pp. 1-6. Available at:

http://konsystest.tanger.cz/files/proceedings/2 1/papers/3932.pdf.

Fahim, M. S., El Faramawy, H., Ahmed, A. M., Ghali, S. N. and Kandil, A. E. H. T. (2013) "Characterization of Egyptian manganese ores for production of high carbon ferromanganese," Journal of Minerals and Materials Characterization and Engineering, 01(02), pp. 68-74.

doi: 10.4236/jmmce.2013.12013.

Kivinen, V., Krogerus, H. and Daavittila, J. (2010) "Upgrading of Mn / Fe ratio of low-grade manganese ore for ferromanganese production," in Vartiainen, A. (ed.) The Twelfth International Ferroalloys Congress Sustainable Future. Helsinki, Finland: Outotec Oyj, pp. 467-476. Available at: https://www.pyro.co.za/InfaconXII/467Kivinen.pdf.

Krivenko, V. V., Ovcharuk, A. N., Taran, A. Y., Filev1, A. S., Oleynik, T. A. and Kharitonov, V. N. (2010) "Investigation of chemical and mineralogical composition of manganese ores from Central Asia deposits," Metallurgical and Mining Industry, 2(1), pp. 7-12. Available at:

https://www.metaljournal.com.ua/assets/Uplo ads/attachments/7Krivenko.pdf.

Pribulova, A., Babic, J. and Baricova, D. (2011) "Influence of hadfields steel chemical composition on its mechanical properties," Chem. Listy, 105, pp. s430-s432. Available at: http://www.chemicke-

listy.cz/docs/full/2011_s4_s430-s438.pdf.

Qian, L., Feng, X. and Zhang, F. (2011) "Deformed microstructure and hardness of hadfield high manganese steel," MATERIALS TRANSACTIONS, 52(8), pp. 1623-1628. doi: 10.2320/matertrans.M2011121.

Ramesh, K., Chen, L., Chen, F., Liu, Y., Wang, Z. and Han, Y.-F. (2008) "Re-investigating the $\mathrm{CO}$ oxidation mechanism over unsupported $\mathrm{MnO}, \mathrm{Mn} 2 \mathrm{O} 3$ and $\mathrm{MnO} 2$ catalysts," Catalysis Today, 131(1-4), pp. 477-482. doi: 10.1016/j.cattod.2007.10.061.

Şeşen, F. E. (2017) "Practical reduction of manganese oxide," Journal of Chemical Technology and Applications, 1(1), pp. 1-2. Available at: http://www.alliedacademies.org/articles/practi cal-reduction-of-manganese-oxide-8311.html.

Sorensen, B., Gaal, S., Ringdalen, E., Tangstad, M., Kononov, R. and Ostrovski, O. (2010) "Phase compositions of manganese ores and their change in the process of calcination," International Journal of Mineral Processing, 94(3-4), pp. 101-110. doi: 10.1016/j.minpro.2010.01.001.

SRK Consulting (2015) Kajian tentang prospek dan deposit mangan di Indonesia.

Tang, Q., Jiang, L., Liu, J., Wang, S. and Sun, G. (2014) "Effect of surface manganese valence of manganese oxides on the activity of the oxygen reduction reaction in alkaline media," ACS Catalysis, 4(2), pp. 457-463. doi: $10.1021 / \mathrm{cs} 400938 \mathrm{~s}$

Wang, Y., Jin, S., Lv, Y., Zhang, Y. and Su, H. (2017) "Hydrometallurgical process and kinetics of leaching manganese from semioxidized manganese ores with sucrose," Minerals, 7(2), p. 27. doi: 10.3390/min 7020027 . 